\title{
DAMPAK PEREKONOMIAN TERHADAP MASYARAKAT MISKIN DI LINGKUNGAN KAMPUNG NELAYAN KECAMATAN MEDAN LABUHAN
}

\author{
FAJRIAWATI \\ Dosen Fakultas Hukum Universitas Muhammadiyah Sumatera Utara \\ email : Fajria.baiqis@gmail.com
}

\begin{abstract}
ABSTRAK
Kemiskinan merupakan masalah yang sangat fatal karena berkaitan dengan ketidak mampuan masyarakat kota Medan yang berdampak pada meningkatnya kebutuhan hidup yang selama ini sangatlah memprihatinkan dengan adanya harga pangan dan papan semakin meningkat dan masyarakat tidak dapat mengimbangi dengan lajunya pertumbuhan ekonomi yang semakin meningkat dan masyarakat tidak dapat mengikuti lajunya perkembangan tersebut dan semakin tertindaslah masyarakat kalangan bawah yang tidak mempunyai penghasilan yang tetap itu sangat berpengaruh pada perekonomian yang dialami oleh masyarakat kota Medan. Berbagai kebijakan dan program yang ada dirasakan semakin kurang efektif dalam upaya menurunkan penduduk yang hidup di bawah garis kemiskinan yang terbukti dari masa ke masa. Dibenahinya kebijakan dan perhatian pemerintah terhadap rakyat miskin harus diperhatikan lebih serius lagi dan dapat memberi lapangan pekerjaan bagi masyarakat yang banyak penganguran diakibatkan tingginya perekonomian yang tidak dapat dijangkau oleh masyarakat kalangan bawah.
\end{abstract}

Kata Kunci: Kemiskinan, Dampak perekonomian

\section{A. PENDAHULUAN}

Kemiskinan di negara sedang berkembang menjadi masalah yang sangat rumit diselesaikan meskipun kebanyakan negara-negara ini sudah berhasil melaksanakan pembangunan ekonominya dengan tingkat pertumbuhan produksi dan pendapatan nasional yang tinggi. Kemiskinan adalah gambaran dari ketidak mampuan seseorang untuk memenuhi kebutuhan sesuai dengan kehidupan yang layak namun kemiskinan itu memiliki ciri-ciri yang berbeda antar wilayah. Sebagai suatu untuk mengukur tingkat kesejahteraan di wilayah tersebut dengan demikian kemiskinan menjadi salah tema utama keberhasilan pembangunan dan kegagalan pembangunan yang acap kali diukur berdasarkan perubahan pada tingkat kemiskinan.

Dewasa ini kemiskinan pedesaan menjadi masalah utama dalam proses pelaksanaan pembangunan di daerah pedesaan. Karena sebagian besar penduduk miskin tinggal di pedesaan dan karakteristik penyebab kemiskinan struktural yang dialami sangat banyak. Kemiskinan terjadi karena kemampuan masyarakat pelaku ekonomi tidak sama, sehingga terdapat masyarakat yang tidak ikut serta dalam proses 
pembangunan atau ditandai dengan pengangguran keterbelakangan dan keterpurukan masyarakat miskin lebih dalam kemampuan berusaha dan mempunyai akses yang terbatas kepada kegiatan sosial ekonomi ( UU no 25 tahun 2000 tentang Propenas).

Suatu konsep pemikiran yang dapat disederhanakan dari sudut pandang pengukuran kemiskinan dibedakan menjadi dua yaitu kemiskinan absolut dan relatif yang kedua dari sudut pandang penyebab kemiskinan dikelompokkan menjadi kemiskinan yang alamiah dan struktural. Kemiskinan merupakan suatu masalah yang dihadapi oleh manusia, dengan kata lain bahwa kemiskinan merupakan suatu masalah sosial yang sifatnya mendunia artinya masalah kemiskinan ini merupakan masalah sosial yang melibatkan berbagai kehidupan manusia. Walaupun dampak dari kemiskinan berbeda-beda.

Walaupun kemiskinan dapat dilihat sebagai masalah multidemensi karena berkaitan dengan ketidak mampuan secara ekonomi, sosial dan budaya, politik dan parti sipasi dalam masyarakat. Miskin memiliki arti yang luas dari sekedar lebih rendahnya tingkat pendapatan atau komsumsi seseorang dari standar kesejateraan diukur sebagai kebutuhan kalori minimum atau garis kemiskinan akan tetapi kemiskinan memiliki arti yang lebih dalam karena berkaitan dengan ketidakmampuan untuk mencapai aspek diluar pendapatan.

Kemiskinan dapat dibagi menjadi tiga kelompok antara lain:

1. Kemiskinan natural yaitu kemiskinan yang mengambarkan fenomena kemiskinan sebagai akibat dari kemiskinan sumber daya alam yang menghidupi masyarakat.

2. Kemiskinan struktual yaitu kemiskinan yang merujuk pada situasi dimana fenomena kemiskinan disebabkan oleh struktur yang membelenggu masyarakat untuk maju secara keseluruhan.

3. Kemiskinan relatif yaitu kemiskinan yang merujuk pada situasi komperasi antara satu individu, kelompok atau masyarakat lainnya.

Sebahagian masyarakat miskin bermukim di pedesaan dan pembangunan pedesaan sebagai dari pembangunan nasional harus mendapat prioritas utama. Konsep ini merupakan upaya penanggulangan kemiskinan yang menempatkan wilayah pedesaan sebagai prioritas dalam peningkatan pertumbuhan ekonomi. Kemiskinan tumbuh sebagian dari masalah dalam kehidupan masyarakat, ini bukan hanya menjadi masalah individu dalam suatu negara tetapi menjadi masalah bangsa dalam rangka globalisasi dan sudah menjadi masalah makro dalam skala makro. Permasalahan kemiskinan pada saat ini sangatlah menjadi persoalan bangsa Indonesia, kemiskinan telah menjadi isu global dari mana setiap negara merasa berkepentingan untuk membahasnya. Berkaitan dengan penanganan kemiskinan di era globalisasi maka sering timbul permasalahan yang dihadapi oleh bangsa Indonesia dengan adanya penganguran dimana-mana penyebab kemiskinan yang tidak dapat di elakkan lagi dengan tingginya pertumbuhan ekonomi yang berdampak pada kemiskinan.

Menurut Tajuddin Noer Effendi ( 1995:215) kebijakan makro dalam memerangi kemiskinan adalah: 
1. Merangsang pertumbuhan ekonomi daerah, terutama pedesaan dengan bantuan INPRES dan BANPRES

2. Penyebaran sarana sosial, seperti Pendidikan kesehatan, air bersih, KB, perbaikan lingkungan ( pertumbuhan).

3. Memperluas jangkauan sarana keuangan dan mendirikan berapa intitusi Kredit

4. Peningkatan sarana produksi pertanian khususnya infastruktur

5. Pengembangan beberapa program pengembangan wilayah seperti pengembangan kawasan terpadu.

Pada sebagian besar pendapat manusia mengenai kemiskinan dan penganguran mengambarkan sisi negatif yaitu pengamen yang membuat tidak nyaman penguna jalan raya, pengemis, gubuk kumuh di bawah jembatan layang yang nampak tidak indah, mencemari sungai karena membuang sampah sembarangan. Dengan demikian kemiskinan dan penganguran sangatlah identik dengan kotor, kumuh sulit diatur, tidak disiplin dan sumber kekacauan dan kejahatan di masyarakat. Indonesia tidak sepenuhnya menganut negara sistem meskipun Indonesia menganut prinsip keadilan sosial ( sila ke 5) dari pancasila. Secara konstitusi pada pasal 27 dan 34 UUD 1945 mengamanatkan tanggung jawab pemerintah dalam pembangunan kesejateran sosial, kemiskinan adalah tanggung jawab bersama.

Kemiskinan dan globalisasi memang sudah bahan perdebatan, bukan hanya kalangan ekonom-ekonom dalam negara maupun luar negari, sejak proses globalisasi mulai berkembang, kondisi kehidupan di hampir semua negara terkesan meningkat, apabila diukur dari indikator-indikator yang lebih luas, negara-negara maju dan kuat memang bisa meraih keuntungan, tetapi tidak dengan negara-negara yang berkembang dan miskin.

Garis kemiskinan adalah tingkat minimum pendapatan yang dianggap untuk memperoleh standar hidup yang mencukupi di suatu negara. Indonesia sebagai negara berkembang dan memiliki jumlah penduduk yang besar tentu tidak terhindar dari masalah tersebut dengan dibuktikan banyaknya masyarakat miskin dan penganguran yang besar, mayoritas yang tinggal di pedesaan yang sulit untuk diakses bahkan di kota besar seperti Jakarta pun juga sangat bayak ditemui masyarakat miskin dan penganguran.

Penanganan dan penanggulangan kemiskinan yang belum sempurna dan belum sepenuhnya berhasil yang terlihat dari tingkat kemiskinan yang masih relatif tinggi yaitu angka diatas 10 persen penduduk miskin di provinsi Sumatera Utara. Persentase penduduk miskin yang ada di Sumatera Utara masih tinggi sekitar 11,3 persen.

Faktor yang mempengaruhi tingkat kemiskinan adalah pertumbuhan ekonomi. Pertumbuhan ekonomi yang tinggi dan disertai pemerataan hasil pertumbuhan keseluruh sektor usaha sangat dibutuhkan dalam upaya menurunnya tingkat kemiskinan. Untuk mempercepat penurunan tingkat kemiskinan. Pertumbuhan ekonomi harus ditingkatkan melalui peningkatan pendapatan rumah tangga. Faktor lain yang mempengaruhi tingkat kemiskinan adalah upah. Upah minimum ditetapkan berdasarkan kebutuhan hidup layak yang dibutuhkan pekerja dengan harapan dapat mendorong peningkatan kesejateraan pekerja sehingga tingkat kemiskinan akan berkurang.

Keterkaitan kemiskinan dan pendidikan sangat besar karena pendidikan memberi kemampuan untuk berkembang lewat penguasaan ilmu dan keterampilan yang pada akhirnya akan meningkatkan produktivitas kerja dan memperbesar peluang kesempatan kerja. Semakin meningkatnya tingkat pengangguran akan semakin mengurangi pendapatan masyarakat yang berakibat naiknya tingkat kemiskinan. 


\section{B. KAJIAN TEORITIS \\ 1. Konsep Kemiskinan}

Menurut sayogyo adalah kemiskinan didasarkan jumlah rupiah Pengeluaran rumah tangga yang disertakan dengan jumlah kiloan koNsumsi beras per orang per tahun dan dibagi di wilayah pedesaan dan perkotaan (Chariswardani Suryawati,2005) Daerah Pedesaan:

a. Miskin, bila pengeluaran keluarga lebih kecil dari pada $320 \mathrm{~kg}$ nilai tukar beras per orang per tahun.

b. Miskin sekali, bila pengeluaran keluarga lebih kecil dari pada $240 \mathrm{~kg}$ nilai tukar beras per orang pertahun.

c. Paling miskin,bila pengeluaran keluarga lebih kecil dari pada $180 \mathrm{~kg}$ nilai tukar beras per orang per tahun.

Daerah perkotaan:

a. Miskin, bila pengeluaran keluarga lebih kecil dari pada $480 \mathrm{~kg}$ nilai tukar beras per orang per tahun.

b. Miskin sekali, bila pengeluaran keluarga lebih kecil dari pada $380 \mathrm{~kg}$ nilai tukar beras per orang per tahun.

c. Paling miskin, bila pengeluaran keluarga lebih kecil dari pada $270 \mathrm{~kg}$ nilai tukar beras per orang per tahun.

Badan Koordinasi Keluarga Berencana Nasional (BKKBN) mengukur kemiskinan berdasarkan dua krIteria (Criswardani suryawati, 2005) yaitu :

a. Kriteria Keluarga Pra Sejatera ( Pra KS) yaitu keluarga yang tidak mempunyai kemampuan untuk menjalankan perintah agama yang baik, minimum makan dua kali sehari, membeli lebih dari satu stel pakaian per tahun, lantai rumah bersemen lebih dari $80 \%$ dan berobat ke puskesmas bila sakit.

b. Kriteria Keluarga Sejatera 1 (KS1) yaitu keluarga yang tidak berkemampuan untuk melaksanakan perintah agama dengan baik, minimal satu kali per mingu daging/telur/ikan, membeli pakaian satu stel per tahun. Rata-rata luas lantai rumah 8 meter persegi per anggota keluarga, tidak ada anggota keluarga umur 10 sampai 60 tahun yang buta huruf, semua anak berumur antara 5 sampai 15 tahun bersekolah, satu dari anggota keluarga mempunyai penghasilan rutin atau tetap dan tidak ada yang sakit selama tiga bulan.

Pada dasarnya kemiskinan yang senantiasa di indentifikasikan dengan taraf hidup yang rendah, dapat diartikan sebagai suatu keadaan penduduk ditandai oleh kekurangan akan kebutuhan pokok. Menurut Widodo ( 1997) menjelaskan bahwa konsep kebutuhan dasar selalu dikaitkan dengan kemiskinan karena masalah kemiskinan merupakan obsesi bangsa dan persoalan amanat mendasar yang harus ditangani pendududk miskin umumnya tidak berpengahasilan cukup, bahkan tidak berpenghasilan sama sekali. Penduduk miskin umumnya lemah dalam kemampuan berusaha dan terbatas aksesnya pada kegiatan ekonomi sehingga tertinggal masyarakat.

Kemiskinan adalah gambaran dari ketidak mampuan sesorang untuk memenuhi kebutuhannya untuk kehidupan yang layak, namun kemiskinan itu memiliki ciri yang berbeda antar wilayah, perbedaan ini pada kemiskinan sumber daya alam, sumber daya manusia dan kelembagaan tersebut. Kemiskinan dipahami sebagai kurangnya pendapatan yang dilakukan oleh rakyat miskin, kurangnya uang dan barang untuk menjamin kelangsungan hidup. Syami (1994) kemiskinan dapat diartikan bahwa suatu keadaan dimana seorang keluarga atau anggota masyarakat tidak mempunyai 
kemampuan untuk memenuhi kebutuhan hidup secara wajar sebagaimana anggota masyarakat lain pada umumnya, Penduduk miskin umumnya berada pada daerah pedesaan.

Pendapatan perkapita keluarga berada dibawah garis kemiskinan, kurang giji, kesehatan yang kurang baik, tingkat kematian bayi tinggi, pendidikan anak masih rendah kualitas perumahan belum memenuhi syarat minimum dan pengeluaran konsumsi pangan yang utama masih belum mencukupi.

\section{Ciri-ciri Kemiskinan}

Ciri-ciri kemiskinan yang ada berbeda antar wilayah, perbedaan ini terkait dengan kemiskinan sumber daya alam, sumber daya manusia dan kelembagaan setempat. Oleh karena itu penangulangan kemiskinan akan lebih efektif kalau dikaitkan dengan prinsip desentralisasi dalam upaya meningkatkan kepedulian dan tanggung jawab pemerintah dan masyarakat.

Mengemukakan ciri-ciri rumah tangga miskin adalah sebagian besar rumah tangga hanya mempunyai satu orang pekerja, sebagian besar tempat tinggal rumah tangga miskin belum memenuhi persyaratan kesehatan yang ada, sebagian besar memiliki lahan relatif kecil. Tingkat pendidikan kepala rumah tangga sebagian masih rendah, rata-rata jam kerja masih rendah jika dibandingkan dengan rumah tangga tidak miskin status pekerjaan $70 \%$ adalah Nelayan.

Masalah kemiskinan tidak lepas dari penyebab kemiskinan tersebut atau kata lain harus mencari akar dan sumber kemiskinan itu sendiri sebenarnya. Untuk mengetahui faktor-faktor penyebab kemiskinan adalah sangat kompleks. Karena kondisi antara satu daerah dengan daerah lainnya beda. Oleh karena itu faktor-faktor penyebab dari kemiskinan adalah berbeda antara derah satu dengan lainya seperti yang dikemukakan terdahulu, meskipun prinsip dasarnya adalah sama.

Pendapat di atas mempunyai penekanan bahwa karakteristik yang ada di daerah perkampungan dapat dilihat dari kondisi perumahan orang-orang dan ketersedian sarana/ prasarana umum dibutuhkan oleh masyrakat. lain:

Dalam proses pembangunan suatu negara ada tiga macam kemiskinan antara

a. Miskin karena miskin, kemiskinan ini disebabkan kemiskinan yang merupakan akibat rendahnya tingkat pendidikan, kesehatan kurang memadai dan kurang terolahnya potensi ekonomi.

b. Kemiskinan yang sebenarnya tidak perlu terjadi dit engah-tengah kelimpahan, kemiskinan yang di sebabkan oleh buruknya daya beli dan sistem yang berlaku.

c. Kemiskinan yang disebabkan karena tidak meratanya serta buruknya pendistribusian produk nasional total ( syahrir, 1986).

\section{Faktor-faktor penyebab kemiskinan}

Faktor-faktor penyebab kemiskinan menurut Kuncoro (1997) antara lain:

a. Secara mikro, kemiskinan muncul karena adanya ketidak samaan pola kepemilikan sumber daya yang menimbulkan distribusi pendapat yang tak seimbang. Penduduk miskin hanya memiliki sumber daya dalam jumlah terbatas dan kualitasnya rendah.

b. Kemiskinan muncul akibat perbedaan dalam kualitas sumber daya manusia yang rendah berarti produktifitasnya rendah yang gilirannya upah rendah. Rendahnya 
kualitas sumber daya manusia karena rendahnya pendidikan, nasib yang kurang beruntung, adanya diskriminasi atau karena keturunan.

c. Miskin muncul karena akibat perbedaan akses dalam modal.

Kemiskinan ada empat penyebab utama antara lain:

a. Rendahnya taraf pendidikan. Taraf pendidikan yang rendah mengakibatkan kemampuan pengembangan diri terbatas dan menyebabkan sempitnya lapangan pekerjaan untuk dimasuki. Dalam bersaing mendapatkan lapangan pekerjaan yang ada, taraf pendidikan juga menentukan. Taraf Pendidikan rendah juga membatasi kemampuan untuk mencari dan memanfaatkan peluang.

b. Rendahnya tingkat kesehatan. Tarif kesehatan dan gizi rendah menyebabkan rendahnya daya tahan fisik dan daya pikir dan prakarsa.

c. Terbatasnya lapangan kerja. Keadaan kemiskinan karena kondisi pendidikan dan kesehatan diperberat oleh terbatasnya lapangan pekerjaan. Selama ada lapangan kerja atau kegiatan usaha, selama itu pula ada harapan untuk memutuskan lingkaran kemiskinan.

d. Kondisi keterisolasian. Banyak pendudduk miskin secara ekonomi tidak berdaya karena terpencil dan terisolasi. Mereka hidup terpencil sehingga sulit atau tidak terjangkau oleh pelayanan pendidikan, kesehatan dan gerak kemajuan yang dinikmati masyarakat.

Faktor-faktor kemiskinan ditinjau dari keadaan sosial budaya yang dikemukakan oleh Kusnaedi (1995) antara lain:

a. Adat istiadat

Keterikatan terhadap pola-pola tradisional dari ikatan adat yang kuat seringkali menghambat dalam pembaharuan ke arah yang lebih maju sehingga tertinggal oleh daerah lain yang lebih respon terhadap teknologi.

b. Pengeluaran dan keterampilan masyarakat

Faktor ini terikat dengan faktor di atas. Akibat keterisolasian dan keterkaitan pada pola tradisional menyebabkan rendahnya pengetahuan dan keterampilan masyarakat tersebut sehingga ketinggalan.

c. Situasi politik dan kebijaksanaan penguasa

Kebijaksanaan ini menyangkut pengalokasian anggaran yang baik yang tidak seimbang antara satu kawasan dengan kawasan lain dan strategi pembanguanan yang timpang antara pertumbuhan ekonomi dengan pemerataan, selain itu dapat diakibatkan oleh kebijaksanaan yang tidak berpihak pada perlindungan terhadap rakyat lemah dari desakan industrialisasi yang kapitalis.

Pendapat dari Amirullah (2001) mengidentifikasi penyebab kemiskinan dipandang dari sisi ekonomi antara lain:

1. Secara mikro kemiskinan muncul karena ketidak samaan pola kepemilikan sumber daya dalam jumlah terbatas dan kualitasnya rendah.

2. Kemiskinan muncul akibat perbedaan dalam kualitas sumber daya manusia.

Kualitas sumber daya manusia yang rendah berarti produktivitas rendah yang pada giliranya upahnya rendah.

Ada dua macam ukuran kemiskinan yang bisa digunakan yaitu kemiskinan absolut dan kemiskinan relatif. Kemiskinan absolut berkaitan dengan tingkat pendapatan dan kebutuhan. Kebutuhan tersebut dibatasi pada kebutuhan pokok atau kebutuhan dasar yang memungkinkan seseorang hidup secara layak. Apabila kebutuhan hidup secara layak. Apabila pendapatan tersebut tidak mencapai kebutuhan minimum maka dapat dikatakan miskin. Kemiskinan dapat diukur dengan 
membandingkan tingkat pendapatan yang diperlukan untuk kebutuhan hidup. Sedangkan kemiskinan relatif yaitu apabila seseorang yang sudah mempunyai tingkat pendapatan yang dapat memenuhi kebutuhan dasar minimum tidak selalu berarti miskin.

Kemiskinan adalah suatu kondisi yang ditandai dengan kekurangan kebutuhan dasar manusia termasuk makan, minum yang aman, kesehatan tempat tinggal dan pendidikan. Kemiskinan merupakan masalah manusia yang telah lama diperbincangkan karena berkaitan dengan tingkat kesejateraan masyarakat dan upaya penanganan. Kemiskinan adalah suatu keadaan dimana tidak sanggup memelihara dirinya sendiri dengan taraf kehidupan yang memiliki dan juga tidak mampu memanfaatkan tenaga, mental maupun fisiknya dalam memnuhi kebutuhannya.

\section{Penyebab terjadinya kemiskinan}

Penyebab kemiskinan sangatlah kompleks sehingga perspektif dalam melihat berdasarkan persoalan real dalam masyarakat. Persoalan real dalam masyarakat biasanya karena adanya sebagian kelompok yang masuk dalam golongan tidak beruntung yaitu kemiskinan fisik yang lemah dan ketidak berdayaan pada umumnya. Di Indonesia penyebab-penyebab kemiskinan adalah sebagai berikut:

a. Kurangnya lapangan pekerjaan yang tersedia di kota Medan

Lapangan pekerjaan yang terdapat di Medan tidak seimbang dengan jumlah penduduk yang ada dimana lapangan pekerjaan yang lebih sedikit dibandingkan dengan jumlah penduduknya.dengan demikian banyak penduduk diMedan Yang tidak memperoleh penghasilan.

b. Laju pertumbuhan penduduk

Pertumbuhan penduduk Indonesia terus meningkat di setiap 10 tahun menurut hasil sensus penduduk. Meningkatnya jumlah penduduk membuat Medan semakin terpuruk dengan keadaan ekonomi yang belum mapan. Jumlah penduduk yang berkerja tidak seimbang dengan jumlah beban ketergantungan. Pengahsilan yang minim ditambah dengan banyaknya beban ketergantungan yang harus ditanggung membuat penduduk dibawah kemiskinan.

c. Angkatan kerja,penduduk yang berkerja dan penganguran.

Secara garis besar penduduk suatu negara dibagi menjadi dua yaitu tenaga kerja dan bukan tenaga kerja. Yang tergolong sebagai tenaga kerja ialah penduduk yang berumur di dalam batas usia kerja. Batas usia kerja berbeda-beda di setiap negara yang satu dengan yang lain. Batas usia kerja yang dianut oleh Indonesia minimum 10 tahun tanpa batas umur maksimum. Jadi setiap orang atau semua penduduk kesenjangan dikatakan lunak, distribusi pendapatan nasional dikatakan cukup merata. Pendapatan penduduk yang dapat dihasilkan yang mereka lakukan relatif tidak dapat memnuhi kebutuhan sehari-hari sedangkan ada sebagian penduduk Indonesia mempunyai pendapatan yang berlebih.

d. Tingkat pendidikan yang rendah

Rendahnya kualitas penduduk juga merupakan salah satu penyebab kemiskinan dan pengangguran di suatu negara, ini disebabkan karena rendahnya tingkat pendidikan dan tingkat pengetahuan tenaga kerja. Untuk adanya perkembangan ekonomi terutama industri jelas sekali dibutuhkan lebih banyak tenaga kerja yang mempunyai skiil atau paling tidak dapat membaca dan menulis. Pada umumnya untuk memperoleh pendapatan yang tinggi diperlukan pendiddikan yang tinggi pula atau minimal mempunyai keterampilan yang memadai sehingga dapat 
memperoleh pendapatan yang dapat memenuhi kebutuhan sehari-hari sehingga kemakmuran penduduk dapat dilaksanakan dengan baik dan kemiskinan dapat ditanggulangi.

\section{Dampak Dari Kemiskinan Terhadap Masyarakat}

Banyak dampak yang terjadi yang disebabkan kemiskinan diantaranya adalah sebagai berikut:

a. Penganguran merupakan dampak kemiskinan, berhubung pendidikan dan keterampilan merupakan hal yang sulit diraih masyarakat. Maka masyarakat sulit untuk berkembang dan mencari pekerjaan yang layak untuk memenuhi kebutuhan, dikarenakan sulit untuk bekerja.

b. Tingkat kematian meningkat, masyarakat Indonesia banyak mengalami kematian karena kelaparan atau melakukan tindakan bunuh diri karena tidak kuat dalam menjalani kemiskinan yang alami.

c. Putus sekolah Tidak bersekolah (tingkat pendidikan yang rendah) ini membuat rakyat Indonesia tidak mempunyai ilmu yang cukup untuk memperoleh pendapatan. Biaya pendidikan penyebab rakyat miskin putus sekolah karena tidak lagi mampu membiayai sekolah, putus sekolah dan hilangnya kesempatan pendidikan akan menjadi penghambat rakyat miskin dalam menambah keterampilan, menjangkau cita-cita mimpi mereka. Ini memyebab kemiskinan yang dalam kareana hilangnya kesempatan untuk bersaing dengan global dan hilangnya kesempatan mendapatkan pekerjaan yang layak.Buruknya generasi penerus adalah dampak yang berbahaya akibat kemiskinan.Jika anak-anak putus sekolah dan berkerja karena terpaksa, maka akan ada gangguan pada anak-anak itu sendiri seperti gangguan pada perkembangan mental dan fisik dan cara berfikir mereka. Contoh anak-anak jalanan yang tak mempunyai tempat tinggal, tidur di jalanan, tidak sekolah, mengamen untuk mencari makan dan lainnya. Generasi penerus merupakan dampak panjang dan buruk karena anak-anak seharusnya mendapatkan hak mereka untuk bahagia, mendapatkan pendidikan, mendapatkan nutrisi baik. Ini dapat menyebabkan mereka terjebak dalam kesulitan hingga dewasa dan dampak pada generasi penerus.

d. Tingkat kejahatan meningkat, masyarakat Indonesia jadi terdesak untuk memperoleh pendapatan dengan cara kejahatan karena dengan cara yang baik mereka tidak mempunyai modal yaitu ilmu dan keterampilan yang cukup.

\section{METODOLOGI PENELITIAN}

Penelitian dilaksanakan di kampung Nelayan Kecamatan Medan Labuhan dengan objek penelitian masyArakat miskin. Populasi adalah keseluruhan subjek atau totalitas subjek penelitian yang dapat berupa orang, benda atau suatu hal yang dimiliki dapat diperoleh atau dapat memberikan informasi data penelitian. Adapun populasi dalam penelitian ini yaitu seluruh kepala keluarga miskin di kampung Nelayan Medan Labuhan. Sampel yang digunakan dalam penelitian adalah cluster sampling yaitu mengelompokan penduduk berdasarkan jenis pekerjaan. Kemudian setiap kelompok akan ditentukan responden dengan metode random sampling sebanyak 29 kepala keluarga setiap kelompok pedagang dan nelayan dengan pertimbangan bahwa Nelayan memiliki karakteristik yang homogen baik dari cara memperoleh usaha nelayan serta sarana yang digunakan. Adapun metodepengumpulan data dilakukan dengan cara: observasi, wawancara dan dokumentasi. Sedangkan metode analisis data yang 
digunakan dalam penelitian ini adalah analisis deskriptif kualitatif yaitu menjelaskan dampak krisis ekonomi terhadap masyarakat miskin di Kampung Nelayan kecamatan Medan Labuhan.

\section{HASIL DAN PEMBAHASAN}

Dampak Perekonomian terhadap masyarakat miskin di Kampung Nelayan di kecamatan Medan Labuhan di identifikasi antara lain pemilik sarana produksi yang masih sederhana antara tanggungan, pendidikan dan keterampilan serta tingkat pendapatan sebagai berikut:

\section{- Tingkat Umur}

Bahwa dari 29 responden masyarakat miskin yang paling dominan adalah yang berumur 30-39 tahun berjumlah 12 responden atau 36,93 persen atau dapat pula dikemukakan bahwa dari 19 responden yang berumur 30-39 tahun terdapat 12 responden atau sekitar 63.30 persen yang taraf hidup miskin. Data ini menunjukan bahwa secara deskriptif ada pengaruh faktor umur terhadap kemiskinan.

\section{Tabel 1}

distribusi Responden Menurut Tingkat Umur di Desa Nelayan Labuhan Kecamatan Medan Labuhan Tahun 2015

\begin{tabular}{|l|l|c|c|c|c|c|}
\hline No & Uraian & $<29$ tahun & $30-39$ tahun & $>40$ tahun & Jumlah & Presentase \\
\hline 1 & Tidak Miskin & 6 & 7 & 7 & 20 & 36.70 \\
\hline 2 & Miskin & 10 & 12 & 9 & 31 & 63.30 \\
\hline & Jumlah & 16 & 19 & 16 & 51 & 100 \\
\hline
\end{tabular}

Sumber : Data Primer Tahun 2015

\section{- Jumlah Tanggungan Keluarga}

Didalam rumah tangga mempunyai jumlah anggota merupakan suatu beban ekonomi yang mempunyai beban sosial yang harus dipikul dipundaknya oleh kepala rumah tangga sebagai tulang punggung untuk mencari nafkah guna untuk memenuhi kebutuhan hidup.

Jumlah yang ditanggung oleh kepala keluarga miskin di desa Kampung Nelayan sangat mempengaruhi tarap hidup masyarakat yang perekonomiannya sangat memprihatinkan dengan kondisi kehidupan ekonomi rumah tangga. Jumlah tanggungan mempengaruhi tingkat pengeluaran konsumsi secara langsung dalam keluarga yang bersangkutan.

\section{Tabel 2}

Responden menurut Jumlah Tanggungan Keluarga Di Desa Nealayan Labuhan Kecamatan Medan Labuhan Tahun 2015

\begin{tabular}{|c|l|c|c|c|c|c|}
\hline No & Uraian & $<2$ ( orang) & $3-4$ (orang) & $>5$ (orang) & Jumlah & Presentase \\
\hline 1 & Tidak miskin & 2 & 10 & 7 & 19 & 36.70 \\
\hline 2 & Miskin & 15 & 20 & 5 & 40 & 63.30 \\
\hline & Jumlah & 17 & 30 & 12 & 59 & 100 \\
\hline
\end{tabular}

Sumber : Data Primer tahun 2015

Berdasarkan Tabel 2 jumlah responden yang memiliki tanggungan 2 orang kebawah atau sama dengan dua sebanyak 17 responden yang memiliki tanggungan 34 orang, yakni berjumlah 20 responden atau 56,18 persen. Atau dapat pula dikatakan bahwa dari 30 responden yang memiliki tanggungan 3-4 orang terdapat 20 responden atau sekitar 60,30 persen yang bertaraf hidup miskin. Dengan demikian secara 
deskriptif dapat dikatakan bahwa kemiskinan masyarakat Desa Nelayan labuhan Kecamatan Medan Labuhan salah satu dipengaruhi oleh jumlah tanggungan dimana semakin tinggi jumlah tanggungan maka tingkat pemenuhan keluarga juga relatif tinggi.

\section{- Pendidikan dan Keterampilan Rendah}

Masalah pendidikan adalah sumber daya manusia dalam pola pikir. Dengan pendidkan yang rendah tidak mampu untuk merubah pola pikir untuk berorentasi ke depan. Dimana tingkat pendidikan di lokasi penelitian rata-rata masih rendah yaitu mayoritas responden masih berpendidikan tamatan Sekolah Dasar dan hanya sedikit tamatan SLTA. Untuk lebih jelas kita lihat pada Tabel 3.

\section{Tabel 3}

Distribusi Responden Menurut Tinggkat Pendidikan Formal

Di Desa kampung Nelayan Kecamatan Medan Labuhan Tahun 2015

\begin{tabular}{|l|l|c|l|l|l|l|}
\hline No & Uraian & $\begin{array}{l}\text { Tdk pernah/ } \\
\text { Tamat SD }\end{array}$ & Tamat SD & $\begin{array}{l}\text { SLTP/ } \\
\text { SLTA }\end{array}$ & Jumlah & Peresentase \\
\hline 1 & Tidak miskin & 10 & 14 & 13 & 37 & 36.70 \\
\hline 2 & Miskin & 23 & 16 & 18 & 57 & 63.30 \\
\hline & Jumlah & 33 & 30 & 31 & 94 & 100 \\
\hline
\end{tabular}

Sumber Data: Data Primer Tahun 2015

Tabel 3 menujukan bahwa masyarakat miskin di desa kampung Nelayan paling dominan tingkat pendidikannya adalah tidak pernah/tidak tamat SD dan tamat SD yakni sebanyak 33 responden atau 75,86 persen. Atau dengan kata lain 33 responden yang mempunyai pendidikan tidak pernah/belum tamat SD dan Tamat SD terdapat 33 responden atau sekitar 75,86 persen yang bertarap hidup miskin. Dengan demikian secara deskriptif, pendidikan merupakan faktor penyebab kemiskinan di kampung nelayan kecamatan Medan labuhan. Rendahnya tinggkat pendidikan maka masyarakat tidak mempunyai akses yang baik terhadap informasi, pengetahuan dan teknologi sehingga akan mempengaruh kemampuannya dalam berfikir untuk beralih pekerjaan lain selain petani dalam mengembangkan usahanya untuk mendapatkan usaha yang paling tinggi.

Tabel 4

Distribusi Responden menurut tinggat pendapatan di Kampung Nelayan Kecamatan Medan Labuhan Tahun 2015

\begin{tabular}{|l|l|c|c|c|c|c|}
\hline No & Uraian & $\begin{array}{l}250.000- \\
500.000\end{array}$ & $\begin{array}{l}500.000- \\
750.000\end{array}$ & $\begin{array}{l}750.000- \\
900.000\end{array}$ & Jumlah & Presentase \\
\hline 1 & Tidak miskin & 0 & 10 & 15 & 25 & 36.70 \\
\hline 2 & Miskin & 23 & 0 & 0 & 23 & 63.30 \\
\hline & Jumlah & 23 & 10 & 15 & 48 & 100 \\
\hline
\end{tabular}

Sumber Data : Data Primer Tahun 2015

Tabel 4 menunjukan bahwa responden yang dimiliki pendapatan rendah sebanyak 23 responden memiliki pendapatan cukup sebanyak 10 responden, memiliki pendapat tinggi sebanyak 15 responden. Dari 23 responden yang memiliki pendapatan rendah yaitu sebesar Rp 250.000-500.000 bertaraf hidup susah dilakukan karena pendapatan mereka mempunyai pengaruh terhadap miskin. 


\section{- Jumlah Tanggungan}

Hasil Penelitian ini diketahui sebagian besar masyarakat miskin di kampung Nelayan kecamatan Medan Labuhan yang memiliki tanggungan yang relatif banyak yaitu 5 orang. Setiap keluarga memiliki tingkat kebutuhan hidup yang relatif tinggi. Tingkat pendapatan keluarga yang tinggi akan berdampak pada perekonomian dan sosial rumah tangga yang memperoleh pendapatan yang rendah. Dalam setiap keluarga hanya satu orang yang bekerja. Kondisi ekonomi dilihat dari kemampuan dalam memenuhi kebutuhan kesehatan dan pendidikan anggota keluarga. Kecilnya pendapatan perkapita sebagai implikasi dari banyaknya jumlah tanggungan keluarga menjadi salah satu faktor penyebab kemiskinan.

Temuan penelitian masyarakat miskin di kampung nelayan sebagian masyarakatnya menjadi buruh dan nelayan ke laut yang sangat sederhana yang digunakan untuk ke laut untuk menangkap ikan dengan menggunakan jala dan membuat tambak-tambak yang ada di pinggiran rawa-rawa untuk menangguk ikan, sarana yang digunakan nelayan masih sangat minim yaitu masih menggunakan tali pancing dan Pukat. Sedangkan dari segi kerja masyarakat miskin masih rendah dan rendah pula pendidikan dan keterampilan yang dimiliki masyarakat. Dengan rendahnya kerja sesorang berpengaruh pada pendapatan, dimana semakin rendah etos kerja seorang maka semakin rendah pula tingkat pendapatannya.

\section{- Program Penangulangan Kemiskinan}

Penanggulangan kemiskinan merupakan program pemerintah adalah suatu tanggung jawab yang harus dilaksanakan pemerintah selama dua dekade pembangunan. Berbagai program anti kemiskinan telah diciptakan untuk memberantas kemiskinan seperti program bantuan modal kerja,transmigrasi dan program inpres.

Berbagai program penangulangan kemiskinan yang telah dilaksanakan pemerintah sebagai berikut: Program Beras Miskin ( Raskin), Program Bantuan Langsung Tunai ( BLT), Program Jaminan pemeliharaan Kesehatan Keluarga Miskin ( JPK GAKIN), Program Asuransi Kesehatan Miskin (Askeskin), Program Bantuan Operasional Sekolah ( BOS), Program Bantuan Khusus Murid ( BKM), Program Jaminan Kesehatan Masyrakat ( Jamkesmas), Program Keluarga Harapan ( PKH), Program penanggulangan kemiskinan Perkotaan ( P2KP).

Perencanaan program anti kemiskinan dilakukan secara serentak baik dari segi bentuk dan model pelaksanaannya tanpa memperhatikan adanya variasi dan berbagai definisi serta sebab terjadinya kemiskinan. Upaya penangulangan kemiskinan tidak hanya sekedar mencakup peningkatan pendapatan golongan masyarakat yang dipandang miskin tetapi dibelakang upaya tersebut banyak hal yang harus dijelaskan. Khususnya untuk kepentingan analisis kebijakan.

Secara teoritis penangulangan kemiskinan dapat dipandang sebagai redistribusi dari golongan masyarakat kaya kepada yang miskin karena kesejahteraan golongan kaya dapat dibandingkan dengan golongan miskin.

Teori yang dijelaskan diatas dapat dilihat dari berapa faktor yaitu:

a. Faktor Ekonomi

Modal yang terbatas dan sulit untuk diperoleh sehingga kehidupan yang dijalani ditambah lagi penduduk miskin tidak memiliki tempat tinggal yang layak apalagi menyangkut kepemilikan rumah. Setatus pekerjaan yang dijalani lebih sering tidak tetap dan bekerja serabutan selama bisa menghasilkan uang akan dijalani 
oleh mereka. Jam kerjanya juga tidak jelas bekerja dalam waktu yang lama tetapi upah yang diperoleh rendah.

b. Faktor Demografi

Kemiskinan yang disebabkan oleh kondisi ekonomi yang ada tetapi kondisi demografis dimulai dari umur pernikahan yang relatif muda sehinggga menghasilkan keturunan sementara pendapatan yang dimiliki tidak cukup untuk memenuhi seluruh keluarga. Hal tersebut menyebabkan kesejahteraan tidak tercapai dalam kehidupan sehari-hari.

c. Faktor Sosial Budaya

Pendidikan yang dimiliki oleh penduduk miskin tergolong rendah karena berbagai faktor terutama terbatasnya perekonomian. Keterampilan yang dimiliki terbatas karena didukung juga pendidikan yang rendah. Seandainya penduduk miskin banyak mengecam pendidikan tinggi selain memperoleh ilmu juga ada keterampilan yang didapat di sekolah.

d. Faktor Lokasi/ Lingkungan

Fasilitas yang ada karena pemukiman masyarakat tesebut cenderung berada di pemukiman kumuh dan berada jauh dari pusat kota. Sulit untuk memperoleh fasilitas karena terhalang jarak. Kesediaan fasilitas juga terhalang karena hal tersebut senantiasa yang dimiliki oleh pemukiman penduduk miskin jauh dari apa yang disebut dengan layak. Sehingga dapat menimbulkan berbagai penyakit bagi penduduk miskin.

\section{E. KESIMPULAN}

Berdasarkan hasil penelitian mengenai Dampak Perekonomian Masyarakat miskin di Kampung Nelayan di kecamatan Medan Labuhan maka penulis mengambil berapa kesimpulan sebagai berikut :

1. Kota Medan khususnya di Kampung Nelayan Kecamatan Medan Labuhan memiliki persentase penduduk miskin yang relatif masyarakatnya masih mengandalkan menangkap ikan di laut yang jumlahnya mencapai 205.100 jiwa atau sekitar 10,03\% dari jumlah penduduk kota Medan pada tahun 2015.

2. Pertumbuhan ekonomi di kota Medan meningkat pertahunnya dengan adanya penyuluhan-penyuluhan yang diberikan oleh instasi pemerintah atau kelompokkelompok kerja yang memberi penyuluhan untuk meningkatnya pertumbuhan di sekitar kampung nelayan agar tarap hidupnya lebih meningkat.

3. Tingkat penganguran yang semakin tinggi akibat dari dampak perekonomian yang sangaat rendah dan pertumbuhan yang dialami oleh masyarakat nelayan tidak sesuai dengan kebutuhan dari hari ke hari yang membuat tingginya pengangguran disebabkan karena laju pertumbuhan angkatan kerja yang jauh melampaui laju pertumbuhan kesempatan kerja.

4. Bahwa pertumbuhan ekonomi dan pendapatan perkapita berpengaruh negatif dan signifikan secara statistik terhadap jumlah masyarakat miskin di kampung Nelayan Kecamatan Medan Labuhan.

\section{DAFTAR PUSTAKA}

Aprilia,Dwi Fitri Kemiskinan sebagai dampak dari Globalisasi.2011

Badan Perencanaan Pembangunan Daerah Sumatera Utara, 2007. Dukungan Provinsi Sumatera Utara dalam Pemberatasan Kemiskinan 
Badan Pusat Statistik, 2009. Medan dalam angka tahun 2015, Medan, Badan Pusat Statistik Sumatera Utara.

Criswardani Suryawati, 2005, Memahami Kemiskinan secara multidimensional.

Dian satria, 2008, Modal Manusia dan globalisasi: Peran Subsidi Pendidikan,

Effendi, Tadjuddin Noer globalisasi dan kemiskinan di Indonesia: Peluang atau Hambatan upaya penangulangan kemiskinan. 2012.

Hermanto siregare dan dwi wahyuniarti, 2008, Dampak Pertumbuhan ekonomi terhadap penurunan jumlah penduduk miskin.

M.Muh Nasir, Saichudin dan Maulizar, 2008, Analisis faktor-faktor yang mempengaruhi kemiskinan Rumah Tangga di kabupaten Purworejo Jurnal Eksekutif Vol. 5 no 4 Agustus 2008, Lipi Jakarta.

Mudrajad kuncoro, 2003, Ekonomi Pembangunan,Teori,Masalah dan kebijakan UPP AMP YKPN, Yokyakarta.

Wongdesmiwati 2009, Pertumbuhan ekonomi dan pengentasan Kemiskinan di Indonesia: Analisis Ekonometrika. 